\title{
Chronicle
}

\section{Marian Smoluchowski: A story behind one photograph}

\author{
A. Ilnytsk $2^{17}$, J. Ilnytsky ${ }^{2}$, Yu. Holovatch ${ }^{2}$, A. Trokhymchuk ${ }^{2}$ \\ ${ }^{1}$ V. Stefanyk Lviv National Scientific Library of Ukraine, 79000 Lviv, Ukraine \\ 2 Institute for Condensed Matter Physics of the National Academy of Sciences of Ukraine, \\ 1 Svientsitskii St., 79011 Lviv, Ukraine
}

Received October 29, 2012, in final form December 3, 2012

We discuss the photograph procured from the archives of the V.Stefanyk Lviv National Scientific Library of Ukraine dated by 1904 which shows Marian Smoluchowski together with professors and graduate students of the Philosophy department of the Lviv University. The personalia includes both the professors and the graduates depicted on the photograph with the emphasis on the graduates as being much less known and studied. The photograph originates from the collection of the Shevchenko Scientific Society, therefore a brief historical background on the activities of physicists in this society around that period of time is provided as well.

Key words: history of science, Shevchenko Scientific Society, Lviv University, Marian Smoluchowski

PACS: $01.60 .+q, 01.65 .+g$

\section{About the photograph and its origin}

Not so many photographs of Marian Smoluchowski are known. To our best knowledge, the photographs representing Marian Smoluchowski together with his colleagues and students are altogether absent. That is why the photograph (see figure 1) recently discovered in the archives of the Institute for Library Art Resources Studies which belongs to the V. Stefanyk Lviv National Scientific Library of Ukraine seems to be especially valuable. The picture on the photograph has dimensions $22.8 \times 29.7 \mathrm{~cm}$ and shows four professors of the Philosophy department of Lviv University and eight 4th year absolvents (graduates). All this information is the part of the handwritten description that is found on the frontside of the photograph and includes the date (June, 1904) and all the names written in Ukrainian. The backside contains the year (1904) and the names written by ink either in Polish or in Ukrainian (possibly at the date the photograph was taken).

The photograph was found among a collection that once belonged to the museum of Shevchenko Scientific Society (abbreviated hereafter as NTSh — from its name in Ukrainian: Наукове Товариство ім. Шевченка) [1, 2]. The NTSh museum was closed in 1940 and, as a result, part of its collection was transferred to the newly established Academic Library in Lviv (now the V. Stefanyk Lviv National Scientific Library of Ukraine). Currently all these materials are stored in the archives of the Institute for Library Art Resources Studies that is part of this library.

The collection of the NTSh museum, including the photographs, was filled-up either by the purchases made by the museum or owing to the gifts obtained from the patrons. New additions were reported systematically in the Chronicle of Shevchenko Scientific Society in the section Museum Status. For instance, in the report for the years 1923-1925, the then manager of the museum Yuriy Polyansky wrote that "the previous years brought further progress into the development of the museum. New exhibits started to be collected and the existing collections enlarged... At the end one needs to note that our citizens started to be interested in the museum fortune. This is evident from quite a number of gifts that arrived at the museum and from the increase of the number of visitors" [3]. How exactly the photograph, which is the 


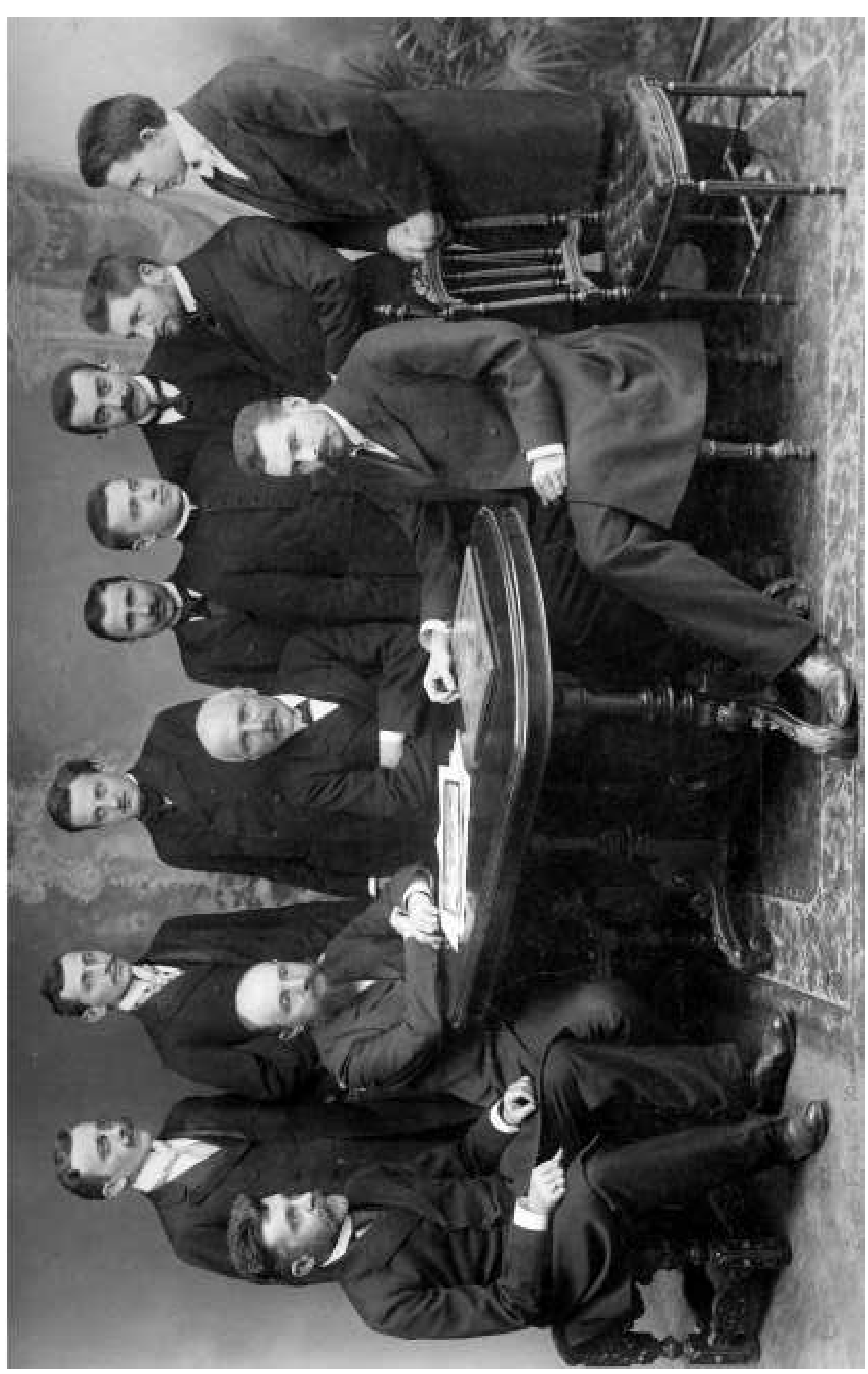

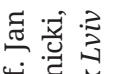

क्ष है है

获

过

$\circ \leqslant$

氖

㐘

踏芯

实高

ब. ज

害掏芯

峲

क⿻

芯芯芯

요

焉

$\underbrace{}_{0}$

प्ते

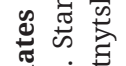

要语

䓪

更

ฐँ

‡ँ के के

马ृ

สิ

낭

क्ष

है

늘

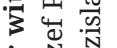

过

㟧

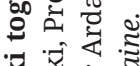

के

है है

층 응 है

क्ष

สี

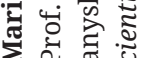

㱐

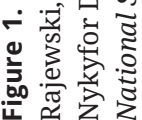


subject of our study, became a part of the collection of the NTSh museum is not known. One of the possibilities is that it might have belonged to Ivan Bodnar, one of the graduates depicted on it, who was president of NTSh during the years 1940-1944, and could have well offered it to the museum.

The NTSh society was founded in Lviv in December 1873. It was named after famous Ukraine's national poet and artist Taras Shevchenko. After being reorganized in 1892, the society acquired features of a typical scientific association and served as the first unofficial Ukrainian Academy of Arts and Sciences. One of its sections was devoted to mathematics, natural sciences and medicine. We will provide here some brief historical account on the development of physics within NTSh society and on the physicists who were members of NTSh.

Various fields of physics were represented in the NTSh society during different time periods of its activity 1 . Among the first full NTSh members (academicians) who were elected in 1899, one finds the names of Ivan Puluj, Volodymyr Levytsky and Petro Ohonovsky. The first of them, Ivan Puluj (1845-1918) is known for his work in the fields of physics, electrical engineering and theology 2 . The major fields of Puluj's interests in physics were molecular physics, cathode rays and X-rays. In particular, by using the electric discharge tubes of his own construction, Puluj obtained fundamental results on cathode rays. Within a variety of vacuum lamps in electrical engineering there is one known as a 'Puluj lamp'. Early in 1896, a month and half after Röntgen's publication on the discovery of X-rays, Ivan Puluj has submitted two papers [8, 9] where he provided a deep explanation of the origin of X-rays and discovered their ionization properties. There are many evidences that the Puluj tube gave the highest quality X-ray pictures [6]. Volodymyr Levytsky (1872-1956) for a long time was the head of the mathematical-natural sciencesmedical section within NTSh and was the NTSh president in 1931-1935. Although his principal field of activity was mathematics, he also contributed to physics by publishing papers, by compiling Ukrainian physical dictionaries, and by writing textbooks on physics in Ukrainian [10]. Another NTSh full member, Petro Ohonovsky (1853-1917) is known as the author of the first physics textbook in Ukrainian [11].

Later on among the full NTSh members one can find more representatives of different fields of physics and engineering. In particular, these are: Yulian Hirniak (1881-1970) — physical chemistry; Roman Tseheljsky (1882-1956) — physics of electrolytes; Volodymyr Kucher (1885-1959) — quantum mechanics and quantum statistics; Stepan Tymoshenko (1878-1972) - mechanics; Ivan Feshchenko-Chopivsky (18841952) - metallurgy; Oleksander Smakula (1900-1983) — optics, known in particular, owing to the discovery of anti-reflective coating of lenses; Andrij Lastovetsky (1902-1943) - spectroscopy; Zenon Khraplyvy (1904-1983) - relativistic quantum mechanics. In 1920-ies Max Plank (1858-1947), Albert Einstein (18791955) and Abram Ioffe (1880-1960) were elected full members of the NTSh society. Many interesting documents about contacts of these and other scientists with the NTSh society are now available in the NTSh archives, main parts of which are stored at the Central State Historical Archive of Ukraine in Lviv [12], V. Stefanyk Lviv National Scientific Library of Ukraine, National Library of Warsaw [13] and some other institutions 3 .

\section{Personalia}

The photograph shown in figure 1 reveals four mature professors sitting in the front, and eight handsome 4th year graduates in their youth (all around 24 years of age) standing behind them. The professors, from left to right, are Jan Rajewski, Ignacy Zakrzewski, Józef Puzyna and Marian Smoluchowski, all of whom were lecturing physics and mathematics in the year the photo was taken. Since the Lviv period of Marian Smoluchowski's life is a subject of a separate paper in this issue [14], we will omit detailed information on Smoluchowski here, referring the readers to the above mentioned sources as well as to references [15-19]. The short information given below concerns other three professors [20-22].

\footnotetext{
${ }^{1}$ Shevchenko Scientific Society was liquidated by Soviet power in 1940, in 1947 it renewed its activity in Western Europe and in the USA, in 1989 it was restored in Ukraine [4, 5].

${ }^{2}$ Together with P. Kulish and I. Nechuy-Levytsky he made the first translation of the Old and the New Testament from Ancient Greek to Ukrainian [6, 7].

${ }^{3}$ See reference [13] for a comprehensive description of main sources.
} 
Jan Rajewski (1857-1906) was born in Lesser Poland4. He attended gymnasiums (high schools) in Drohobych and Lviv. During 1875-1879 Jan Rajewski studied mathematics and physics in the Philosophy department of the Lviv University and in 1884 he received here a doctoral degree. In the 1883-1890 Rajewski worked as a school teacher of mathematics and physics in Lviv, Stanislav and Kraków. In 1900 Rajewski became an extraordinary professor of mathematics at Lviv University. His works are devoted to the theory of differential equations. He is buried in Lviv at Lychakiv Cemetery.

Ignacy Zakrzewski (1860-1932) was born in Ternopil and graduated from Lviv University in 1882. He worked at Lviv University (1882-1886), at Kraków University (1887-1891), and studied at Berlin University (1892). In 1893 Ignacy Zakrzewski became a professor. During 1892-1920 he was head of the chair of experimental physics at Lviv University. Main scientific interests include physics of ice and temperature behavior of the heat capacity of solids.

Józef Puzyna (1856-1919) was born in Novy Martyniv (province of Stanislav5). In 1875 he finished the gymnasium in Lviv and studied mathematics at Lviv University. After defending a doctoral thesis in 1883, Puzyna continued his studies at Berlin University, where one of his teachers was Karl Weierstrass. Since 1885 Puzyna lectured at Lviv University and in 1892 he became an ordinary professor and headed the chair of mathematics. During 1905 (the next year after the photograph in figure 1 was taken) Józef Puzyna was rector, and in 1906 - vice rector of Lviv University. Puzyna's main field of activity was the theory of analytic functions. Among his students there were Volodymyr Levytsky, Hugo Steinhaus, Antoni Łomnicki, Waclaw Sierpinski.

Obviously, all professors shown in the photograph were already well established in their career whereas the destiny of the eight young men after graduation from the Lviv University could provide a high-quality literary plot (in a way German romanticist E.T.A. Hoffmann was inspired by the engravings by Jacques Callot in his Fantasiestücke in Callots Manier). We intentionally concentrated on the life stories of the graduates, as far as these are much less known as compared to that of their teachers.

The first standing from the left is Józef Bartkiewicz and to our regret we found nothing on his biography data. The second standing from the left is Ivan Bodnar (Іван Боднар). The following information can be found in the Encyclopedia of Modern Ukraine [23]. Ivan Bodnar was born on 1 September, 1880 in the village Vovkiv (now Peremyshlyany district of Lviv region). From 1900 Bodnar attended Vienna University. In 1905 he graduated from the Philosophy department of Lviv University. Then, Ivan Bodnar taught mathematics and physics at Ternopil Teachers Training Seminary (1906-1921) and later on at both Peremyshl Gymnasium and Ternopil Gymnasium (1921-1931). In 1930th he worked at the Ternopil Ukrainian Bank, and in 1940-1941 and 1944-1950 at the Academic Library in Lviv (now V. Stefanyk Lviv National Scientific Library of Ukraine). During 1941-1944 Ivan Bodnar worked as an accountant at the Lviv City administration.

More sketches to the personality of Ivan Bodnar can be found in the historical studies, especially on his involvement in politics in 1918 [24] and his role in the social and cultural life of Ternopil in 19201930 [25, 26]. In particular, Ivan Bodnar is mentioned as head of the Teachers' Society and co-founder of the Ladies Institute in Ternopil [26]. Among others, Ivan Bodnar was a subject of coordinated night searches performed by authorities in September 1930.

Since 1910 Ivan Bodnar was a member of the NTSh. During 1939-1940 he was vice-president and in 1940-1946 he was president of the NTSh. Professor Ivan Bodnar died on 18 December, 1968 in Lviv [23].

According to the indication on the front side of the photograph, the third graduate from the left is Antoni Łomnicki. Although the handwriting on the back side is not so clear (reads more like "Hordynski"), we are quite sure that this must be Łomnicki6.

Antoni Łomnicki was born on 17 January, 1881 in Lviv. He studied at the Lviv University and the University of Göttingen, attending courses given by H. Minkowski, D. Hilbert and F. Klein7. In 1920 Łomnicki became a professor of Lviv Polytechnic and his field of interests included mathematical analysis, probabilistics, statistics, cartography, didactics, applied mathematics. In 1938 Łomnicki became a member of the Warsaw Scientific Society (TWN) [27]. In 1920-1922, one of the founders of modern functional analysis Stefan Banach was an assistant of Prof. Łomnicki. Later Łomnicki was a major adviser for Banach’s

\footnotetext{
${ }^{4}$ Malopolska (Polish), which is one of the historical regions of Poland, its capital is the city of Kraków.

${ }^{5}$ Ivano-Frankivsk at present.

${ }^{6}$ We compare the image in figure 1 with the later photographs of professor Antoni Łomnicki.

${ }^{7}$ D. Hilbert and F. Klein were members of the NTSh.
} 
doctoral thesis until his habilitation at Lviv University.

Antoni Łomnicki tragically died on 4 July, 1941 in Wzgórza Wuleckie (part of Lviv) in the massacre of Lviv professors by Nazi occupation forces [28]. In December 1944 Stefan Banach wrote the following tribute to professor Łomnicki: "A native of Lviv, he worked for over twenty years as a mathematics professor at Lviv Polytechnic. He prepared hundreds of engineers for their profession. I was his assistant. He was the first to instil in me the importance and responsibility of a professor's task. He was an unrivaled educator, one of the best I have ever known. He was the author of many popular schoolbooks as well as textbooks on advanced analysis for technologists, surpassing in quality those published abroad. His work in the field of cartography was of a high level. Equally effective were his efforts as an instructor and pedagogue. Professor Łomnicki had tremendous energy and a great work ethic” [29].

The fourth graduate from the left is Nykyfor Danysh (Никифор Даниш). Hе was born in 1877. After graduating from Lviv University Nykyfor Danysh dedicated himself to teaching, was active as an organizer of various private schools in Kolomyia and Stanislav. In particular, in 1908 Nykyfor Danysh started teaching at Kolomyia Ukrainian Gymnasium, alongside with Roman Shypaylo, another graduate depicted on the photograph that we are discussing [30]. Danysh wrote several books on the history of the Kolomyia Gymnasium [30, 33]. In turmoil of the end of 1918, Nykyfor Danysh was a member of the of the West Ukrainian People's Republic (ZUNR) administration in Chortkiv (Ternopil region) [31].

In 1921, being a member of the Ukrainian Teachers Society, Nykyfor Danyzh established the Ukrainian Ladies Gymnasium in Stanislav and became its first director. The memoirs of a former student of this gymnasium gave him an account of being a great teacher and the true patriot [32]. Nykyfor Danysh can be found in the photograph of all graduates of Kolomyia Gymnasium during the years 1914-1939 (see photo in reference [34], where Nykyfor Danysh is eighth from the left sitting in the first row). Nykyfor Danyzh immigrated to United States where he died in 1954 [35].

The fifth graduate from the left is Reverend Volodymyr Ardan (о. Володимир Ардан). Не was born in Polyany, Korosnyansky povit (Lemkivshchyna region) and was a professor of mathematics in the State Ukrainian Gymnasium in Peremyshl [37]. In 1905 he took an active position establishing a pre-gymnasium hostel for pupils coming from the nearby villages and until 1910 was a director of this hostel [36].

In 1934 the Roman Throne established the Lemky Apostle Administration and Rev. V. Ardan became a member of the Lemky Capitula in Rymanov, holding a position of synod judge [37]. In his memoirs Rev. V. Hrynyk also recalls Volodymyr Ardan as a great mathematician and teacher in the Peremyshl Gymnasium and mentions that he was arrested during the Nazi occupation for unclear reasons [38].

The sixth graduate from the left is Zdzislaw Thullie. He was a son of a well known scientist, Prof. Maksymilian Thullie (1853-1939), twice rector of the Lviv Politechnic, expert in bridge construction, senator and an active Christian-Democrat politician. Zdzislaw Thullie was interested in the theory of metals. We found his paper (in Polish) published in 1908 [39, 40] and a book (in French) published in 1912 [41]. He was also a professor and taught physics at the first Lviv Real School.

Zdzislaw Thullie was in the middle of his career and was to be habilitated soon when his life was abruptly terminated by a tragic accident that happened on 16 June, 1922. The story (based on contemporary newspapers) is retold by Stanisław S. Nicieja [42]. Z. Thullie together with two other professors (Łopuszański and Zagórski) took a large group of their students for a trip to Bubnyshcha (rocky region near Bolekhiv, now Ivano-Frankivsk district) to have some leisure before the exams. The sunny day was spent among the rocks, and the night - inside the tents. On the next day, after breakfast, all walked back towards the train station to return to Lviv in time for the teachers conference (in which the professors participated). However, around noon, a sudden storm with lightning broke up. Z. Thullie with two students separated from the rest and stopped by the river to watch for rough waves. Professor, in romantic mood, said to pupils: “Watch, guys, what a wonderful and at the same terrifying view!". Next moment the lightning tore the sky with the roar and Prof. Thullie fell down struck by it. None of immediate first aid measures could help as the death was instantaneous, and the most that students could do was to bring the body to Lviv for the funeral which took place a few days later and was attended by many.

The seventh graduate from the left is Roman Shypaylo (Роман Шипайло). After graduation, since 1906 he worked as a teacher in Kolomyia Ukrainian Gymnasium, alongside with Nykyfor Danysh [30]. Besides teaching mathematics and physics, Roman Shypaylo was also known as a great enthusiast of Ukrainian choir music. He organized and directed the school choir which performed much of the avail- 
able contemporary Ukranian repertoire (among others, such large-scale compositions as Kavkaz by S. Ludkevych and Haydamaky by J. Kyshakevych) [43]. In the newspapers of that time one can find the articles by R. Shypaylo [44]. Mary Beck (1908-2005), the first woman elected to Detroit’s City Council, who studied in 1920th in Kolomyia, characterized Shypajlo as a former soldier (he served in the Ukrainian Galician Army, UHA), having a romantic soul and as a great admirer of photography [46]. Roman Szypajlo also initiated and patronized the 13th girls Plast (Ukrainian scout) regiment.

The rightmost graduate depicted in the photograph is Ivan Sitnytsky (Іван Сітницький). Не was born on 25 June, 1881 in Komarno (the village near Lviv) and died on 10 October, 1947 in Lviv [47]. Ivan Sitnytsky taught exact sciences at Lviv Academic Gymnasium [48]. He published several textbooks on geometry, chemistry and physics. Sitnytsky was a member of the NTSh. Similarly to Roman Shypaylo, Sitnytsky also served as a centurion in the UHA. Early in 1919 the Artillery School was established in Stryi, then it was moved to Stanislav. The school was well equipped for teaching and supplied with a good amount of cannons and horses. After its first commandant officer was moved to another regiment, his place was taken by Ivan Sitnytsky [49].

The jubileum book for the Lviv Academic Gymnasium [50] contains numerous references and memoirs concerning Prof. I. Sitnytsky. It is mentioned that he taught mathematics in higher classes introducing Ukrainian terminology. The lectures on physics were also given by him (reference [50], p. 467). Together with Dr. Chaikivsky they lectured the seminar Problems and methods in Physics in the Circle for Natural sciences (reference [50], p. 179).

\section{Instead of summary}

Marian Smoluchowski (1872-1917) was an outstanding scientist, one of the founders of the modern statistical physics. His life was bright but, unfortunately, very short. Native Polish, Marian Smoluchowski was born in Vienna and lived there until receiving a doctoral degree. At the age of forty five Marian Smoluchowski unexpectedly died in Kraków, shortly after moving there from Lviv, where he spent his fourteen most fruitful years in science. Although there are numerous studies [14, 17,-19] dedicated to the life and scientific activities of Marian Smoluchowski, some questions still remain open. One of them concerns the pupils and/or coworkers that Smoluchowski could have in Lviv. The present sketches do not answer these questions directly, but still shed some light regarding the scientific (and, to some degree, political) atmosphere at those times. We hope that both the photograph and our sketchy study, could be helpful for those interested in the history of science and physics in particular.

\section{Acknowledgement}

We are thankful to Yaroslav Hrytsak, Roman Plyatsko and Halyna Svarnyk for useful suggestions.

\section{References}

1. See, e.g. Internet Encyclopedia of Ukraine, http://www.encyclopediaofukraine.com

2. Doroshenko. V., A source of Ukrainian science: T. Shevchenko Scientific Society, New York-Philadelphia, 1951 (in Ukrainian).

3. Polyanskyi Y., Museum status. Information on the museum for years 1923-1925. Shevchenko Scientific Society Chronicles for years 1923-1925. Lviv, 1926, vol. 67-68, p. 142-146 (in Ukrainian).

4. Holovatch Yu., Ukr. Fiz. Zh., 1992, 37, 468 (in Ukrainian).

5. Holovatch Yu., Ukr. Fiz. Zh., 1992, 37, 474 (in Ukrainian).

6. Gajda R., Plazko R., Johann Puluj. Rätsel des universalen Talents, EuroWelt-Verlag, Lwiw, 2001 (in German).

7. Puluj I., Collection of papers, Shenderovsky V. (Ed.), Rada, Kyiv, 1996.

8. Pului J., Über die Entstehung der Röntgen’schen Strahlen und ihre photographische Wirkung, Wiener Berichte, 1896, Bd. 105, s. 228-238 (in German).

9. Pului J., Nachtrag zur Abhandlung: Über die Entstehung der Röntgen'schen Strahlen und ihre photographische Wirkung, Wiener Berichte, 1896, Bd. 105, s. 243-245 (in German). 
10. Levytsky V., Physics for higher classes, Lviv, 1912 (first edition), 1923-1924 (second edition, in two parts, in Ukrainian).

11. Ohonovsky P., Handbook of physics for lower classes of secondary school, Lviv, 1897 (in Ukrainian).

12. Central State Historical Archive of Ukraine in Lviv, fond 309.

13. Svarnyk H., Archives and manuscripts of the Shevchenko Scientific Society in the holdings of the National Library of Warsaw. Catalogue. Ukrainian Archives \& Shevchenko Scientific Society, Warsaw-Lviv-New York, 2005 (in Ukrainian).

14. Rovenchak A., Condens. Matter Phys., 2012, 15, 41002;

15. From Brownian motion to power of fluctuations. Special issue of the Condens. Matter Phys., 2012, 15, No. 4, devoted to M. Smoluchowski 140th birth anniversary, Berche B., Holovko M., Trokhymchuk A., Vlachy V. (Eds.).

16. From Brownian motion to self-avoiding walks and Lévy flights. Special issue of the Eur. Phys. J. ST, 2013, 216, devoted to M. Smoluchowski 140th birth anniversary, von Ferber C., Holovatch Yu., Mryglod I., Oshanin G. (Eds.) (in press).

17. Teske A., Marian Smoluchowski: życie i twórczość, PWN, Kraków, 1955 (in Polish).

18. Teske A., Marian Smoluchowski: Leben und Werk, Wroclaw-Warszawa-Kraków-Gdansk, 1977 (in German).

19. Chandrasekhar S., Kac M., Smoluchowski R., Marian Smoluchowski: his life and scientific work, PWN, Warsaw, 2000.

20. Duda R., Lwowska szkoła matematyczna, Wydawnictwo Uniwersytetu Wrocławskiego, Wrocław, 2007 (in Polish).

21. Holovatch Yu., Plyatsko R., Physicists and chemists at the University of Lviv/Lwów/Lemberg in the second half of the 19th century - the beginning of the 20th century, In: The Global and the Local: The History of Science and the Cultural Integration of Europe. Proceedings of the 2nd ICESHS (Cracow, 2006), Kokowski M. (Ed.), The Press of the Polish Academy of Arts and Sciences, Cracow, 2007, 388.

22. Encyclopedia. Ivan Franko National University of Lviv, Lviv, 2011.

23. The Encyclopedia of Modern Ukraine, Kyiv, 2004, vol. 3, p. 162.

24. Lazarovych M., The second capital of ZUNR, “Ji” magazine, 2010, 63, 57-77 (in Ukrainian), http://www.ji.lviv.ua/n63texts/N63-ternopil.htm

25. Ostapiuk B., Bohdan Lepkyi in Ternopil in 1929, In: On the roads of golden Podillia, Philadelphia, 1970, vol. II, 108-109, reprinted by “Ji” magazine, 2010, 63, 115-116 (in Ukrainian), http://www.ji.lviv.ua/n63texts/N63-ternopil.htm

26. Boytsun L., Ternopil in a flow of years, Dzhura, Ternopil, 2003, 389 p. (in Ukrainian), http://tarnopol.te.ua/books/book_2.html

27. Wielka Encyklopedia PWN, Warszawa, 2003, Tom 16, p. 290 (in Polish).

28. Albert Z., Execution of Lviv professors in July of 1941, Wroclaw University, 1989, 382 p. (in Polish).

29. http://en.wikipedia.org/wiki/Antoni_\%C5\%81omnicki

30. Danysh N., Sketch on the history of the Ukrainian Gymnasium in Kolomyia from its beginning 1892/3 to 1911/12, Kolomyia, 1912, 52 p. (in Ukrainian).

31. http://library.iv-fr.net/2007/06/18/page,13,organzacja_civlno_vladi_zunr_u_povtakh_galichini_listopad_gruden_ 1918_roku.html (in Ukrainian).

32. Lemekha-Lutska O., On the footpaths of the youth (on the occasion of 50 years of maturity exam in Ukrainian Ladies Gymnasium Ridna shkola in Stanislav), Svoboda, Ukrainian diary, year XC, No. 65, 8 April 1983 (in Ukrainian), http://www.svoboda-news.com/arxiv/pdf/1983/Svoboda-1983-066.pdf

33. Danysh N., Life of Ukranian youth in Kolomyia gymnasium, in Nasha shkola (published by the society of teachers community in Lviv), Lviv, 1910, vol. II, p. 32-34 (in Ukrainian).

34. Rev. Fedunyk Ya., My Kolomyia (on the history of Kolomyia gymnasium) (in Ukrainian), http://kolomyya.org/histpub/historypub63.htm.

35. Ukrainians in the World (in Ukrainian), http://www.ukrainians-world.org.ua/ukr/about/45/49/86/91/

36. Schach S., Where the blue Sian flows, memorable episodes in the history of Ukrainian high school in Peremyshl, Ukrainian School Association Ridna Shkola in Germany, Ukrainian Printing in Brussels-Belgium, 1977, p. 39 (in Ukrainian), http://www.apokryfruski.org/wp-content/uploads/2011/03/mnib646-Sah-DeSribnolentyjSjanPlyve.pdf

37. Shakh S., In between Sian and Dunajets', Memoirs, Khrystyjanskyi Holos, Munchen, 1960, part 1, p. 25 (in Ukrainian), http://www.apokryfruski.org/wp-content/uploads/2011/03/mnib645-Sah-MijSjanomIDunajzem.pdf

38. Memoirs of Rev. Vasyl Hrynyk, Basilian Order Archive, Warszawa, vol. XIV, No. 6, units 4.1 and 4.2 , http://www.bazylianie.pl/?option=com_content\&view=article\&id=1221 (in Ukrainian).

39. Thullie Z., O niektórych zagadnieniach elektronowej teoryi metali. Prace Matematyczno-Fizyczne, Towarzystwo Naukowe Warszawskie, Wydzial III Nauk Matematyczno-Fizycznych, 1908, Vol. 19, No. 1, p. $207-215$ (in Polish), http://matwbn.icm.edu.pl/ksiazki/pmf/pmf19/pmf19110.pdf 
40. Thullie Z., Pola molekularne i ich znaczenie w Teoryi Magnetyzmu i w Optyce, Prace Matematyczno-Fizyczne, Towarzystwo Naukowe Warszawskie, Wydzial III Nauk Matematyczno-Fizycznych, 1913, Vol. 24, No. 1, p. 315-335 (in Polish), http://matwbn.icm.edu.pl/ksiazki/pmf/pmf24/pmf2416.pdf

41. Thullie Z., Contribution à la théorie des effets galvano- et thermomagnétiques, L’Université, 1912, 27 p., http://books.google.de

42. Nicieja S.S., Moje Kresy. Bolechów i jego legendy (1), Nto.pl, 17 December 2011, (in Polish) http://www.nto.pl/apps/pbcs.dll/article?AID=/20111217/REPORTAZ/5877088

43. Mykytiuk Ya., On beginnings of a sole Ukrainian symphonic orchestra in Halychyna (in Ukrainian), http://kolomyya.org/histpub/historypub73.htm

44. Shypaylo R., Choir of the students of the Theological Academy, Dilo, 1935/234.

45. Nahirnyi V., Plast is 100 years old, Kolomyjski visti, 10 March 2012, (in Ukrainian) http://visty.in.ua/home/kmnews/748-lr-100-.html

46. Nahirnyi V., Lady from the first, Den', 2 May 2012, (in Ukrainian) http://incognita.day.kiev.ua/ledi-z-pershix.html

47. Encyclopedia Ukrainoznavstva, Kubiyovych V. (Ed.), Molode zhyttja, Paris, New-York, 1954-1989.

48. Tomeniuk O., Pedagocical activity of professor Yuriy Polanskyi in Lviv Academic Gymnasium, Materials and studies for archaelogy of Prykarpattia and Volyn', 2009, iss. 13, p. 322-335.

49. Tkachuk P.P., Commanders of land forces of Halytska Army in 1918-1919, Military-scientific bulletin, 2008, iss. 10, p. 187-200, (in Ukrainian) http://www.nbuv.gov.ua/portal/soc_gum/vnv/|

50. Jubileum book of Ukrainian Academic Gymnasium in Lviv, O. Dombrovskyi (Ed.), Philadelphia-Lviv, 1995, part 3, $896 \mathrm{p}$.

\title{
Маріан Смолуховський: історія одного фото
}

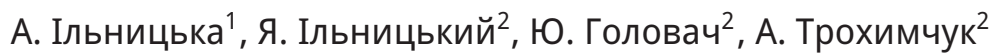 \\ 1 Львівська національна наукова бібліотека України ім. В. Стефаника, 79000 Львів, Україна \\ 2 Інститут фізики конденсованих систем НАН України, вул. Свєнціцького, 1, 79011 Львів, Україна
}

Розглянуто фотографію датовану 1904 роком з Архіву Львівської національної наукової бібліотеки ім. В. Стефаника, на якій зображено професорів та випускників четвертого року навчання філософського факультету Львівського університету. Світлина походить із колекції Наукового Товариства ім. Шевченка, тому подано коротку історичну довідку про діяльність цього товариства на межі XIX-XX століть. Персоналія включає коротку довідку про зображених на фото професорів та ширшу інформацію про випускників (як таку, яка менш доступна в довідкових джерелах).

Ключові слова: історія науки, Наукове Товариство ім. Шевченка, Львівський університет, Маріан Смолуховський 